\title{
Kinetochore components are required for central spindle assembly
}

Gilliane Maton, Frances Edwards, Benjamin Lacroix, Marine Stefanutti, Kimberley Laband, Tiffany Lieury, Taekyung Kim, Julien Espeut, Julie C. Canman and Julien Dumont

Nat. Cell Biol. 17, 697-705 (2015); published online 13 April 2015; corrected after print 8 June 2015

In the version of this Letter originally published, the following sentence was omitted from the Acknowledgements: 'B.L. is supported by a post-doctoral fellowship from FRM (ARF20140129055). This has been corrected in the online versions of the Letter.

\section{MCUR1 is an essential component of mitochondrial $\mathrm{Ca}^{2+}$ uptake that regulates cellular metabolism}

Karthik Mallilankaraman, César Cárdenas, Patrick J. Doonan, Harish C. Chandramoorthy, Krishna M. Irrinki, Tünde Golenár, György Csordás, Priyanka Madireddi, Jun Yang, Marioly Müller, Russell Miller, Jill E. Kolesar, Jordi Molgó, Brett Kaufman, György Hajnóczky, J. Kevin Foskett and Muniswamy Madesh

Nat. Cell Biol. 14, 1336-1343 (2012); published online 25 November 2012; corrected after print 10 June 2015

In the version of this Letter originally published, a key funding source was omitted from the Acknowledgements. César Cárdenas's credit should have read 'C.C. was supported by the Fondo Nacional de Desarrollo Cientifico y Tecnologico (FONDECYT) grant \#1120443 and an award from the American Heart Association'. 